\title{
Yenidoğan Umblikal Kord Özelliklerinin Göbek Düșme Süresine Etkisi
}

\author{
Effects of Newborn Umblical Cord Properties on the Cord Separation Time
}

\author{
Ayden ÇOBAN $^{1}{ }^{\oplus}$, Ayten TAŞPINAR ${ }^{1} \odot$, Seher KARABUDAK ${ }^{2}$, $^{\text {, }}$
}

\author{
Hatice KARATEPE ${ }^{30}$ \\ ${ }^{1}$ Aydın Adnan Menderes Üniversitesi Sağılk Bilimleri Fakültesi, Ebelik Bölümü, Aydın, Türkiye \\ ${ }^{2}$ Aydın Adnan Menderes Üniversitesi Hemşirelik Fakültesi, Çocuk Sağlı̆̆ı ve Hastalıkları Hemşireliği A.D, Aydın, Türkiye \\ ${ }^{3}$ Aydın Adnan Menderes Üniversitesi Araştırma ve Uygulama Hastanesi, Kadın Doğum Kliniği, Aydın Türkiye
}

ÖZ

\begin{abstract}
Amaç: Bu çalışma, yenidoğanın umblikal kord özelliklerinin göbek düşme süresine etkisini belirlemek amacı ile yapılmıştır. Yöntem: Analitik nitelikte olan çalışma, 1 Eylül 2015 ile 1 Eylül 2016 tarihleri arasında, batıda yer alan bir üniversite hastanesinde, 90 anne ve yenidoğan ile yapılmıştır. Araştırmanın iki aşaması vardır. İlk aşamada doğum sonu dönem 0 . günde anne ve yenidoğana ait özellikler değerlendirilmiştir. Araştırmanın ikinci aşaması ise birinci görüşmeden en az 15 gün sonra anneler ile telefonla görüşülerek tamamlanmıştır. Verilerin değerlendirilmesinde sayı, yüzde dağılımları belirlenmiş, $t$ testi, Mann Whitney U analizi yapılmıştır.

Bulgular: Yenidoğanların \%63.3'ü 38-41. gebelik haftası arasında, \%86.7'si sezaryenle doğmuş olup, ortalama $3099 \pm 48$ gr ağırlığında ve $49.85 \pm 2.42 \mathrm{~cm}$ boyunda, umblikal kord klemp mesafesi medyan değeri $2 \mathrm{~cm}$, kord çevresi medyan değeri 1.5 $\mathrm{cm}$ olduğu bulunmuştur. Yenidoğanların göbeğinin düşme süresi ortalama 8.5 gün olarak tespit edilmiştir. Yenidoğanların \%82.2'sinin göbek bakımı yapılmadığı ve kuru bırakıldığı, 14'ünde (\%15.6) umblikal kord enfeksiyonu geliştiği tespit edilmiştir. Araştırmada yenidoğanların doğum şekli ve Rh uyuşmazlığı durumu ile göbek düşme süresi arasında istatistiksel olarak anlamlılık saptanmıştır $(\mathrm{p}<0.05)$. Umblikal kord klemp mesafesi ve kord çevresi uzunluğu ile yenidoğanın göbeğinin düşme süresi arasında ise istatistiksel olarak anlamlı ilişki saptanmamıştır ( $\mathrm{p}>0.05)$.

Sonuç: Yenidoğanların göbek düşme süresi ile umblikal kord özellikleri (klemp mesafesi ve kord çevresi uzunluğu) arasında ilişki saptanmamıştır. Ayrıca sezaryen ile doğan yenidoğanlarda göbek düşme süresinin daha uzun, RH uyuşmazlığı sorunu yaşayan yenidoğanlarda ise daha kısa olduğu tespit edilmiştir.
\end{abstract}

Anahtar Kelimeler: Umblikal kord, Göbek düşme süresi, Yenidoğan, Bakım.

\section{ABSTRACT}

Objective: This study was carried out to determine the effect of newborn umbilical cord properties on cord separation time. Methods: The analytical study was conducted in a western university hospital with 90 mothers and newborns between September 1, 2015 and September 1, 2016. The research has two stages. At the first stage, maternal and newborn characteristics were evaluated at postpartum period day 0 . At the second stage of the research, the mother was called at least 15 days after the first interview and the cord separation time form was filled. Number and percentage distributions were determined, and $t$ test, Mann Whitney U analysis are utilized.

Results: $63.3 \%$ of newborns are born between $38-41$ th gestational week. $86.7 \%$ of them were born with caesarean section and they were found to have a mean weight of $3099 \pm 48 \mathrm{gr}$ and a length of $49.85 \pm 2.42 \mathrm{~cm}$. The umbilical cord clamp median distance was $2 \mathrm{~cm}$, and the cord periphery median was $1.5 \mathrm{~cm}$. The cord separation time was 8.5 days on average. $82.2 \%$ of the newborns were found to have no umbilical care and were left dry, and 14 (15.6\%) developed umbilical cord infections. Statistical significance was determined between the birth type of the newborns, the Rh disagreement status and the umbilical cord separation time $(\mathrm{p}<0.05)$. There was no statistically significant relationship between the umbilical cord clamp distance, the cord periphery and the cord separation time ( $p>0.05)$.

Sorumlu Yazar: Ayden ÇOBAN

Aydın Adnan Menderes Üniversitesi Sağlık Bilimleri Fakültesi, Aydın, Türkiye

ayden.coban@adu.edu.tr

*Bu makale 03-05 Mayıs 2018 tarihinde, Amasya’da düzenlenen 5. Uluslararası 9. Ulusal Ebelik Öğrencileri Kongresinde

poster olarak sunulmuştur.

Geliș Tarihi: 09.02.2020 - Kabul Tarihi: 17.03.2020 
Conclusion: No relation was found between the umbilical cord characteristics (clamp distance and cord circumference length) of the newborns and the cord separation time. But in newborns born with caesarean section, the cord separation time is longer, and in newborns with RH dispute problems, it is shorter.

Key words: Umbilical cord, Cord separation time, Newborn, Care.

\section{GíRiş}

Umblikal kord kesildikten sonra göbek bağı, bakterilerin gelişmesi için uygun ve nekrotik bir alan yaratarak, yenidoğanı enfeksiyon açısından riskli hale getirir (1,2). Bu özelliği ile göbek bağı enfeksiyon ajanları için uygun bir giriş kapısıdır. Göbek bağı enfeksiyonu ise yenidoğanın mortalite ve morbitidesinin en önemli nedenlerindendir (3). Dünya Sağlık Örgütü (DSÖ) ve Birleşmiş Milletler Çocuklara Yardım Fonu (UNICEF) 2018 raporlarında her yıl tüm dünyada 2,6 milyon bebeğin ilk ayını tamamlayamadan öldüğünü, yenidoğan ölümlerinin ise \%15'inden göbek bağı enfeksiyonlarından kaynak alan bakteriyel enfeksiyonların sorumlu olduğu bildirilmiştir $(4,5)$.

Göbek bağı enfeksiyonuna neden olan bakteriyel kolonizasyon oluşumunu önlemek için kord bakımında kullanılan antiseptikler ise kordun düşme süresini uzatmakta $(1,2)$, bu da farklı enfeksiyon ajanlarının üremesine neden olmaktadır (6). Bu nedenle artık kord bakımında hiçbir antiseptik kullanılmamakta doğal kurutma uygulanması önerilmektedir. Yani göbek bağı açık, temiz ve kuru tutulmaktadır $(2,7)$.

Yine göbek bağı enfeksiyonu oluşmasında etkili olan kordun düşme süresini uzatan faktörlerden bir diğeri sezaryen doğumlardır $(6,8)$. Bunun dışında prematüre bebekler ile düşük doğum ağırlıklı bebeklerin, enfeksiyon nedeniyle antibiyotik kullanan bebeklerin ve erkek cinsiyetteki bebeklerin kord düşme sürelerinin uzadiğ 1 belirtilmektedir $(2,9,10)$. Cinsiyet konusunda farklı bilgiler de mevcuttur. Bazı çalışmaların sonuçları erkek bebeklerde kordun daha erken düştügünü göstermiştir $(2,6,9,10)$. Aynı zamanda anne sütüyle beslenmenin kord düşme süresini kısalttı̆̆ı saptanmıştır (6).

Normal koşullarda göbek kordonu doğumdan sonraki 5-15. günler arasında kurur ve düşer. Özellikle enfeksiyon açısından ciddi risk oluşturan kordun düşme süresinin uzamasına yol açan faktörlerin belirlenmesi son derece önemlidir. Göbeğin düşmesini geciktiren diğer bir faktör ise umblikal kord özelliklerinden kord klemp mesafesi ve kordon çevre uzunluğu olabilir. $\mathrm{Bu}$ çalışmanın amacı yenidoğanın umblikal kord özelliklerinin göbek düşme süresine etkisini belirlemektir.

\section{GEREÇ VE YÖNTEMLER}

Araştırma analitik-kesitsel tipte olup, ülkemizin batısında yer alan bir üniversite hastanesinin kadın doğum kliniğinde, 1 Eylül 2015 ile 1 Eylül 2016 tarihleri arasında doğum yapan anne ve yenidoğan bebekleri ile yapılmıştır. Araştırmanın örneklemini belirlemede daha önce aynı konuda yapılmış bir çalışma olmaması nedeniyle orta etki değer olan 0.30 alınmıştır (11). G*Power 3.0.10 programında yapılan güç analizinde $t$ testi kullanılarak \%80 güçle, \%95 güven aralığında, etki büyüklüğü 0.30 (orta etki) alınarak yapılan ölçümde; araştırmanın örneklem sayısı en az 64 olarak hesaplanmış çalışmaya 90 anne ve bebeği dahil edilmiştir.

Araştırmaya herhangi bir kronik hastalığı bulunmayan (diyabet, hipertansiyon, troit v.b.), 20-35 yaş grubunda, sağlıklı ve tek bebeği olan anneler alınmıştır. Bebeğinde umblikal 
kord anomalisi olan (uzun kordon, kordon dolanması v.b.) anneler araştırmaya dahil edilmemiştir.

Araştırma iki aşamada gerçekleştirilmiştir. Araştırmanın ilk aşaması; araştırmacılardan olan klinik bebek hemşiresi annelere çalışma hakkında bilgi verdikten sonra araştırmaya davet etmiştir. Araştırmaya katılmak için gönüllü annelerden yazılı onam alınmıştır. Daha sonra annelere hazırlanan anket formu doldurulmuştur. Anket formu annelerin sosyodemografik özellikleri, doğum haftası, doğum şekli ve yenidoğanın APGAR skoru, cinsiyeti, RH uyuşmazlığı varlığına ilişkin soruları içermektedir. Ayrıca yenidoğanın boyu, kilosu, göbek kordonu klemp mesafesi ve göbek kordonu çevresi standart bir mezura ile aynı araştırmacı tarafindan ölçülmüştür.

Araştırmanın ikinci aşamasında: anneler ilk görüşmeden 15-20 gün sonra telefonla aranılarak göbek düşme zamanı, göbek bakımı yapılma durumu, göbekte kanama, pis koku, kızarıklık, akıntı olup olmadığı, anne sütü alma durumu ve bebeklerin genel sağlık durumları öğrenilmiştir. Çalışmanın ikinci görüşmesinde üç kez kendisi ve verdiği ikinci numara telefonla aranılıp ulaşılamayan anneler çalışmadan çıkarılması planlanmış fakat böyle bir durumla karşılaşılmamıştır.

\section{Araştırmanın Etik Yönü}

Araştırmanın yapılabilmesi için hastaneden gerekli izin ve yazarların bulunduğu Üniversitenin Tıp Fakültesi Girişimsel olmayan klinik araştırmalar etik kurulundan (protocol no:2015/635) etik onay ve annelerden de bilgilendirilmiş onam alınmıştır.

\section{Verilerin Analizi}

Araştırmadan elde edilen veriler Statistical Package fort he Social Version 22.0 (SPSS) Paket programı kullanılarak analiz edilmiştir. İstatistiksel değerlendirmelerde anlamlılık düzeyi $\mathrm{p}<0.05$ olarak alınmıştır. Verilerin normal dağılıma uygunluğu shapiro-wilk testi ile test edilmiş, normal dağılım gösteren sürekli değişkenlerin analizinde independent sample t testi, normal dağılım göstermeyen sürekli değişkenlerin analizinde ise Mann Whitney U testi, Kruskal Wallis Varyans analizi, sperman korelasyon kullanılmıştır. Kategorik değişkenlerin analizinde Ki-Kare testi kullanılmıştır. Sonuçlar ortalama, standart sapma, median, sayı ve yüzde olarak ifade edilmiştir.

\section{BULGULAR}

Araştırmaya katılan annelerin sosyo-demografik verileri incelendiğinde; annelerin \%42.2'sinin ilköğretim mezunu, \%70'inin çalışmadığ 1 , eşlerinin ise \%37.8'i ilköğretim mezunu, \%95.6'sının herhangi bir işte çalıştığı belirlenmiştir. Annelerin \%51.1'inin ilçede yaşadığ,$\% 72.2$ 'sinin gelirinin giderine denk ve \%95.6'sının sağlık güvencesinin olduğu bulunmuştur (Tablo 1).

Tablo 2'de yenidoğanların bazı özelliklerine göre kord düşme süresi karşılaştırılmıştır. Sezaryenle doğan bebeklerin vajinal yolla doğan bebeklere göre göbek bağı düşme süreleri daha uzun bulunmuş ve istatistiksel olarak da bu durum anlamlı olduğu tespit edilmiştir. Yenidoğanların \%8.9'unda (sekiz yenidoğanda) Rh Uyuşmazlığı olduğu tespit edilmiş olup 
göbek düşme süreleri diğer yenidoğanlardan anlamlı derecede daha kısa bulunmuştur $(\mathrm{p}=0.016)$.

Tablo 1. Annelerin Sosyo-Demografik Özellikleri

\begin{tabular}{|c|c|c|}
\hline $\begin{array}{ll} & \text { Sosyo-demografik özellikler } \\
\text { Eğitim durumu } & \end{array}$ & Sayı & $\%$ \\
\hline Okur-yazar değil/okuryazar & 5 & 5.6 \\
\hline İlköğretim mezunu & 38 & 42.2 \\
\hline Lise mezunu & 18 & 20.0 \\
\hline Üniversite mezunu & 29 & 32.2 \\
\hline \multicolumn{3}{|l|}{ Eşin Eğitimi } \\
\hline Okur-yazar değil/okuryazar & 1 & 1.1 \\
\hline İlköğretim mezunu & 34 & 37.8 \\
\hline Lise mezunu & 32 & 35.6 \\
\hline Üniversite mezunu & 23 & 25.6 \\
\hline \multicolumn{3}{|l|}{ Annenin çalışma durumu } \\
\hline Çalışıyor & 27 & 30.0 \\
\hline Çalışmıyor & 63 & 70.0 \\
\hline \multicolumn{3}{|l|}{ Eşin Çalışma Durumu } \\
\hline Çalışıyor & 86 & 95.6 \\
\hline Çalışmıyor & 4 & 4.4 \\
\hline \multicolumn{3}{|l|}{ Yaşanılan yer } \\
\hline Köy & 5 & 5.6 \\
\hline İlçe & 46 & 51.1 \\
\hline Şehir & 39 & 43.3 \\
\hline \multicolumn{3}{|l|}{ Ailenin gelir durumu } \\
\hline Gelir giderden az & 18 & 20.0 \\
\hline Gelir gidere denk & 65 & 72.2 \\
\hline Gelir giderden fazla & 7 & 7.8 \\
\hline \multicolumn{3}{|l|}{ Sağlık Güvencesi } \\
\hline Yok & 4 & 4.4 \\
\hline Var & 86 & 95.6 \\
\hline
\end{tabular}

Tablo 2. Yenidoğanların Bazı Özelliklerine Göre Göbek Kordonu Düşme Sürelerinin Karşılaştırılması

\begin{tabular}{|c|c|c|c|}
\hline \multicolumn{2}{|l|}{ Özellikler } & \multicolumn{2}{|c|}{ Göbek kordonu düşme süresi (gün) } \\
\hline Doğum haftası & Sayı (\%) & Ort (SD) & $\mathbf{p}$ \\
\hline 34-37 hafta & $33(36.7)$ & $8.48(3.40)$ & $.425^{\mathrm{a}}$ \\
\hline 38-41 hafta & $57(63.3)$ & $9.84(4.43)$ & \\
\hline \multicolumn{4}{|l|}{ Doğum Şekli } \\
\hline Vajinal doğum & $12(13.3)$ & $7.42(2.81)$ & $.040^{\mathrm{a}}$ \\
\hline Sezaryen & $78(86.7)$ & $9.79(4.17)$ & \\
\hline \multicolumn{4}{|l|}{ Bebeğin kilosu (Mean: $3099 \pm 486.28$ ) } \\
\hline 2500gr altında & $13(14.4)$ & $9.69(4.33)$ & $.839^{\mathrm{b}}$ \\
\hline 2500gr ve üzerinde & $77(85.6)$ & $9.44(4.08)$ & \\
\hline \multicolumn{4}{|l|}{ Bebeğin Boyu (Mean: 49.85 \pm 2.42 ) } \\
\hline $50 \mathrm{~cm}$ altında & $35(38.9)$ & $9.34(3.99)$ & $.805^{\mathrm{b}}$ \\
\hline $50 \mathrm{~cm}$ ve üzerinde & $55(61.1)$ & $9.56(4.18)$ & \\
\hline \multicolumn{4}{|l|}{ Cinsiyeti } \\
\hline K1Z & $48(53.3)$ & $9.10(3.50)$ & $.657^{\mathrm{a}}$ \\
\hline Erkek & $42(46.7)$ & $9.90(4.68)$ & \\
\hline \multicolumn{4}{|l|}{ 1. Dakika Apgar Skoru (Med: 8 IR(25-75): 8-9) } \\
\hline 7 & $9(10.0)$ & $12.00(5.85)$ & $.320^{\mathrm{c}}$ \\
\hline 8 & $56(62.2)$ & $9.12(3.88)$ & \\
\hline 9 & $25(27.8)$ & $9.36(3.67)$ & \\
\hline \multicolumn{4}{|l|}{ 5. Dakika Apgar skoru (Med: 9 IR(25-75): 9-10) } \\
\hline 8 & $2(2.2)$ & $7.00(2.82)$ & $.641^{\mathrm{c}}$ \\
\hline 9 & $62(68.9)$ & $9.51(4.27)$ & \\
\hline 10 & $26(28.9)$ & $9.57(3.76)$ & \\
\hline \multicolumn{4}{|l|}{ Rh Uyușmazlığı } \\
\hline Var & $8(8.9)$ & $6.37(1.30)$ & $.016^{\mathrm{a}}$ \\
\hline Yok & $82(91.1)$ & $9.78(4.14)$ & \\
\hline \multicolumn{4}{|l|}{ Bebeğin beslenme șekli } \\
\hline Sadece anne sütü & $65(72.2)$ & $9.47(4.10)$ & $.960^{\mathrm{a}}$ \\
\hline Diğer (formül mama, anne sütü, su vb.) & $25(27.8)$ & $9.48(4.14)$ & \\
\hline
\end{tabular}


Tablo 3'te umblikal kord özelliklerinin kord düşme süresi ile ilişkisi verilmiştir. Yenidoğanların 1. dk APGAR skorları ile 5. dk APGAR skorları arasında pozitif yönde yüksek bir ilişki saptanmıştır $(\mathrm{r}=0.876 \mathrm{p}=0.000)$. Yenidoğanların umblikal kord klemp mesafesi ile kord çevresi arasında pozitif yönde $(\mathrm{r}=0.496 \mathrm{p}=0.000)$, göbek düşmeden banyo yapılma sayısı ile negatif yönde zayıf ilişki belirlenmiştir $(\mathrm{r}=0.443 \mathrm{p}=0.022)$. Yenidoğanların göbek düşme süresi ile ilk banyo zamanı (gün) pozitif yönde orta ilişki ( $\mathrm{r}=0.643 \mathrm{p}=0.000)$, göbek düşmeden silme banyo yapılma sayısı ile pozitif yönde çok zayıf bir ilişki $(r=0.253 \mathrm{p}=0.027)$ tespit edilmiştir. Yenidoğanların ilk banyo zamanı (gün) ile göbek düşmeden silme banyo yapılma sayısı arasında pozitif yönde orta düzeyde bir ilişki saptanmıştır ( $\mathrm{r}=0.511 \mathrm{p}=0.000)$.

Tablo 4'te umblikal kord özelliklerine göre kord düşme süresinin karş1laştırılması verilmiştir. Yenidoğanların umblikal kord klempleme mesafesi medyan değeri $2 \mathrm{~cm}$, kord çevresi median değeri $1.5 \mathrm{~cm}$ ve göbek düşme süresi median değeri 8.5 gün olarak bulunmuştur. Yenidoğanların doğumdan sonra ilk banyo yaptırılma zamanı 9 gün bulunmuş ve günde $6 \mathrm{kez}$ alt değiştirildiği öğrenilmiştir.

Yenidoğanların \%95.6'sının göbeği hiçbir müdahale olmadan kendiliğinden düşmüştür. Yenidoğanların \%17.8'inin göbeğine alkol, batikon, zeytinyağı vb. maddelerle bakım yapılmıştır. Göbek bakımı yapılan yenidoğanlarla yapılmayan yenidoğanların göbek düşme süreleri arasında istatistiksel olarak anlamlı farkın olmadığı belirlenmiştir $(p=0.706)$. Yenidoğanda enfeksiyon gelişme, göbek düşmeden banyo yaptırılma, göbek düşmeden silme banyo yaptırılma durumuna göre göbek düşme süresi arasında anlamlı bir fark bulunmamıştır. Yenidoğanların tümünde hazır bez kullanıldığı öğrenilmiştir (Tablo 4). Yenidoğanların çoğunun (\%93.3) bezini göbek kordonunun altından bağlandığı tespit edilmiştir. Yenidoğanların \%12.2'sinin spanç veya tülbent vb. gibi materyallerle göbek kordonunun kapatıldığı saptanmıştır. Yenidoğanların \%44.4'ünün göbek kordonu idrar ya da gaita ile temas etmiş, \%32.2'si yenidoğan döneminde hastalık geçirmiş, \%60.0'ının cildine nemlendirici (zeytinyağı, losyon, krem, bebek yağı) sürülmüştür. Yenidoğanların bezinin göbek kordonunun altından bağlanma, göbek kordonunun kapatılma, göbek kordonunun idrar ya da gaita ile temas etmesi, hastalık geçirme ve cildine nemlendirici sürme durumlarına göre göbek düşme süreleri arasında istatistiksel anlamlı fark saptanmamıştır (Tablo 4).

\section{TARTIŞMA}

Araştırma yenidoğanın umblikal kord özelliklerinin göbek düşme süresine etkisini belirlemek amaciyla 90 anne ve yenidoğan ile doğumdan sonra ilk gün ve en az 15 gün sonra olmak üzere iki aşamada gerçekleştirildi. Araştırmada göbek düşme süresi anne, yenidoğan ve umblikal kord özellikleri bakımından karşılaştırıldı.

Göbek kordonu genellikle postpartum 5-15 gün içinde kurur ve düşer $(1,12)$. Araştırmada göbek kordonunun düşme süresi ortalama 8.5 gün olarak literatüre uygun bulunmuştur. Yenidoğanların \%95.6'sının göbeği hiçbir müdahale olmadan kendiliğinden düşmüştür. Yenidoğanların \%17.8'inin göbeğine alkol, patikon, zeytinyağı vb. maddelerle bakım yapılmıştır. Göbek bakımı yapılan yenidoğanlarla yapılmayan yenidoğanların göbek düşme süreleri arasında istatistiksel olarak anlamlı farkın olmadığı belirlenmiştir. Göbek düşme süresi ile göbek bakımda alkol, klorheksidin, anne sütü kullanımını ele alan çalışmalarda göbek düşme süresi farklılık göstermektedir $(3,9,13,14)$. Oysa Dünya Sağlık Örgütü, yenidoğanların 
Adnan Menderes Üniversitesi Sağlık Bilimleri Fakültesi Dergisi 2020: 4(2); 81-89 Journal of Adnan Menderes University Health Sciences Faculty

Tablo 3. Yenidoğanların Bazı Özelliklerine Göre Göbek Kordonu Düşme Sürelerinin Karşılaştırılması

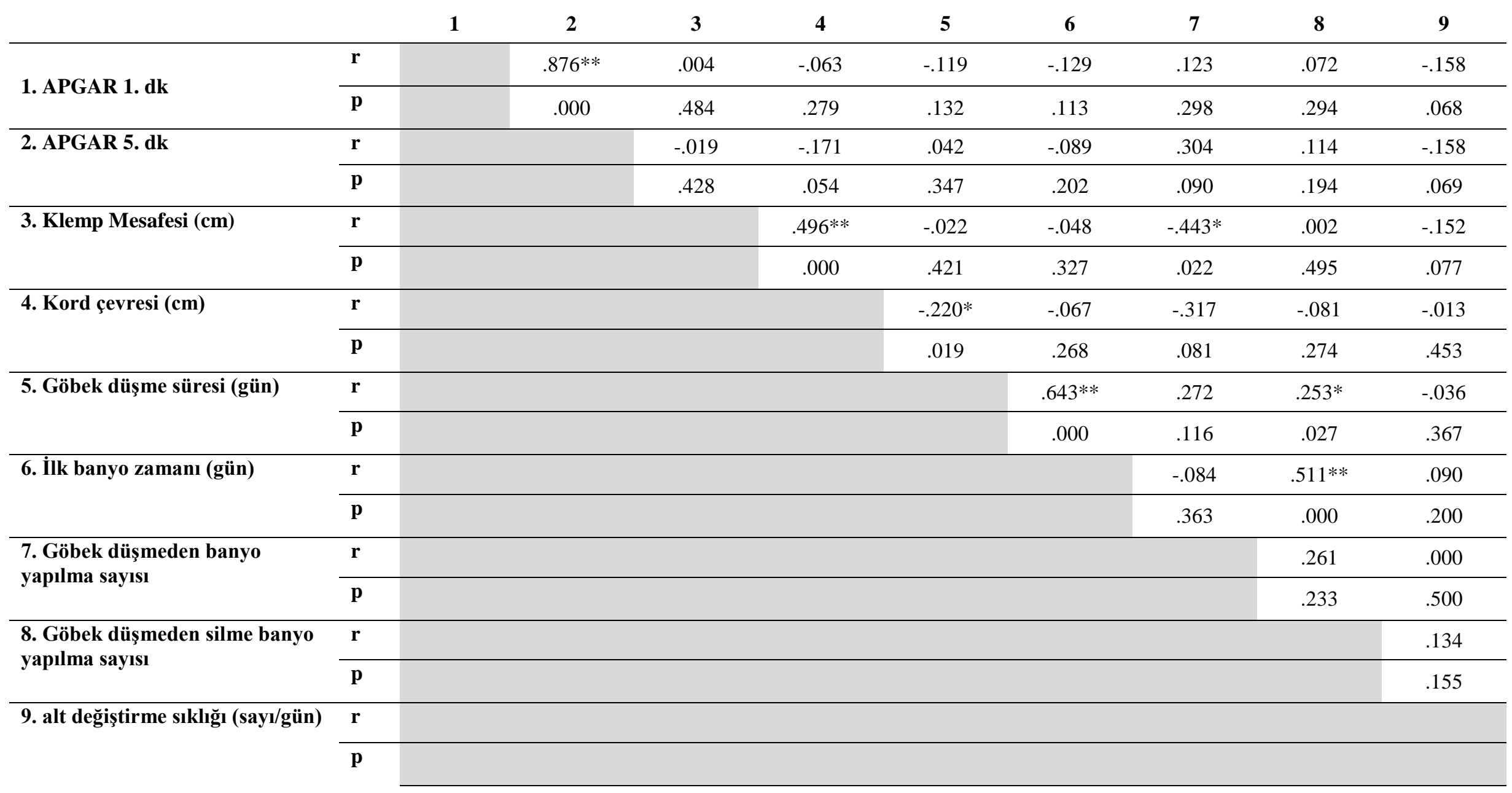

** Correlation is significant at the 0.01 level (2-tailed).

* Correlation is significant at the 0.05 level (2-tailed). 
göbek kordonu bakımında kuru bakım yapılmasını önermektedir (7). Çalışmada göbeğin kuru tutulduğu yani hiçbir bakım malzemesi kullanmayan annelerin çoğunlukta olduğu dikkat çekmektedir.

Tablo 4. Umblikal Kord Özellikleri ve Bu Özelliklere Göre Kord Düşme Süresinin Karşılaştırılması

\begin{tabular}{|c|c|c|c|}
\hline Umblikal kord özellikleri & Median & \multicolumn{2}{|l|}{ IR (25-75) } \\
\hline Umblikal kord klemp mesafesi $(\mathrm{cm})$ & 2 & \multicolumn{2}{|l|}{$1.75-2.50$} \\
\hline Umblikal kord çevresi (cm) & 1.50 & \multicolumn{2}{|l|}{$1-2$} \\
\hline Göbek kordonu düşme zamanı (gün) & 8.50 & \multicolumn{2}{|l|}{$7-12$} \\
\hline İlk banyo yaptırılma zamanı (doğumdan sonra gün) & 9 & \multicolumn{2}{|l|}{$7-14.50$} \\
\hline Bebeğin altının değiştirilme sıklığı (kez/gün) & 6 & \multicolumn{2}{|l|}{$5-8$} \\
\hline & & \multicolumn{2}{|c|}{ Göbek kordonu düşme süresi } \\
\hline Göbek bakımı yapılma durumu & Sayı (\%) & Ort (SD)/ Med (IR) & $\begin{array}{c}\text { Test } \\
\text { değeri }\end{array}$ \\
\hline Evet & $16(17.8)$ & $9.12(3.72)$ & $\mathrm{t}=0.093$ \\
\hline Hayır & $74(82.2)$ & $9.55(4.18)$ & $\mathrm{p}=0.706$ \\
\hline \multicolumn{4}{|l|}{ Enfeksiyon gelişme durumu } \\
\hline Evet & $14(15.6)$ & $9.57(2.87)$ & \multirow{2}{*}{$\begin{array}{l}\mathrm{t}=0.093 \\
\mathrm{p}=0.926\end{array}$} \\
\hline Hayır & $76(84.4)$ & $9.46(4.29)$ & \\
\hline \multicolumn{4}{|l|}{ Göbek düşmeden banyo yaptırılma durumu } \\
\hline Evet (Median:1.86 kez IR (25-75): 1-2.50) & $19(21.1)$ & $9.66(3.62)$ & \multirow{2}{*}{$\begin{array}{l}\mathrm{t}=0.240 \\
\mathrm{p}=0.811\end{array}$} \\
\hline Hayır & $71(78.9)$ & $9.42(4.24)$ & \\
\hline \multicolumn{4}{|l|}{ Göbek düşmeden silme banyo yaptırılma durumu } \\
\hline Evet (Median: 2 IR (25-75): 2-3) & 59 (65.6) & $9.86(83.86)$ & \multirow{2}{*}{$\begin{array}{l}\mathrm{t}=-1.280 \\
\mathrm{p}=0.204\end{array}$} \\
\hline Hayır & $31(34.4)$ & $8.70(4.47)$ & \\
\hline \multicolumn{4}{|l|}{ Göbek kordonunun kapatılma durumu } \\
\hline Evet (spanç, tülbent vb.) & $11(12.2)$ & $9.09(3.41)$ & \multirow{2}{*}{$\begin{array}{l}\mathrm{t}=-.333 \\
\mathrm{p}=0.740\end{array}$} \\
\hline Hayır & $79(87.8)$ & $9.53(4.19)$ & \\
\hline \multicolumn{4}{|l|}{$\begin{array}{l}\text { Göbek kordonunun idrar ya da gaita ile temas } \\
\text { durumu }\end{array}$} \\
\hline Evet & $40(44.4)$ & $8.67(3.42)$ & \multirow{2}{*}{$\begin{array}{l}\mathrm{t}=1.682 \\
\mathrm{p}=0.096\end{array}$} \\
\hline Hayır & $50(55.6)$ & $10.12(4.48)$ & \\
\hline \multicolumn{4}{|l|}{ Yenidoğanın hastalık geçirme durumu } \\
\hline Evet (sarllık, ishal, konjoktivit, enfeksiyon) & $29(32.2)$ & $9.55(4.68)$ & \multirow{2}{*}{$\begin{array}{l}\mathrm{t}=1.118 \\
\mathrm{p}=0.907\end{array}$} \\
\hline Hayır & $61(67.8)$ & $9.44(3.81)$ & \\
\hline \multicolumn{4}{|l|}{ Cildine nemlendirici sürülme durumu } \\
\hline Evet & $54(60.0)$ & $9.63(4.09)$ & \multirow{2}{*}{$\begin{array}{l}\mathrm{t}=0.303 \\
\mathrm{p}=0.762\end{array}$} \\
\hline Hayır & $34(40.0)$ & $9.37(4.12)$ & \\
\hline
\end{tabular}

Literatürde umblikal kord klempinin abdominal duvardan 2-3 cm uzaklıkta mesafeye yerleştirilmesi ve kesilmesi önerilmektedir $(15,16)$. Çalışmada da literatüre uygun bir şekilde yenidoğanların umblikal kord klempleme mesafesi medyan değeri $2 \mathrm{~cm}$ bulunmuştur. Çalışmada umblikal kord özelliklerinden olan klemp mesafesi, kord çevresi, göbek düşmeden banyo yapılma sayısı ve alt değiştirme sıklığı ile göbek düşme süresi arasında anlamlı bir ilişki saptanmamıştır. İlk banyo yapma zamanı ile orta, göbek düşmeden silme banyo sayısı ile zayıf ilişki saptanmıştır.

Yenidoğanların doğumdan sonra ilk banyo yaptırılma zamanı 9 gün bulunmuş ve günde 6 kez alt değiştirildiği öğrenilmiştir. Yenidoğanda enfeksiyon gelişme, göbek düşmeden banyo yaptırılma, göbek düşmeden silme banyo yaptırılma durumuna göre göbek düşme süresi arasında anlamlı bir fark bulunmamıştır. Yenidoğanların tümünde hazır bez kullanıldığı 
öğrenilmiştir. Bu sonuçlar araştırmanın üçüncü basamak bir sağlık kuruluşunda yapılmış olması ve belirli bir sosyo-kültürel düzeydeki annelerle çalışılmış olmasından kaynaklanabilir.

Araştırmada doğum haftası erken olanlarla normal doğum zamanında doğan yenidoğanların göbek düşme süreleri benzer bulunmuştur. Oysa farklı çalışmalarda gestasyonel yaşın göbek düşme süresini etkilediği bildirilmektedir (17). Bu farklılık çalışmamızda çok düşük gestasyonel haftalarda doğan bebeklerin yer almaması, en düşük 34 en yüksek 41 gestasyonel haftasında doğan yenidoğanların yer almasından kaynaklanabilir.

Hsu ve ark. 2010 yaptıkları çalışmada sezaryen doğum şeklinin göbek düşme süresini uzattığı belirlenmiştir. Çalışmada sezaryenle doğan bebeklerin vajinal yolla doğan bebeklere göre göbek düşme süreleri daha uzundu. Bu bulgu literatürle benzerlik göstermektedir.

Literatürde yenidoğanın doğum ağırlığının göbek düşme süresi ile ilişkili olduğu bildirilmiştir $(2,9,10)$. Çalışmada ise yenidoğanların doğum kilosu bakımından karşılaştırma yapılmış fakat 2500 gramın altında doğanların üstünde doğanlarla ve $50 \mathrm{~cm}$ altında doğan bebeklerin 50 ve üzerinde doğan bebeklerle göbek düşme süreleri benzer bulunmuştur. $\mathrm{Bu}$ durum çalışmamızda yenidoğanların ortalama doğum ağırlı̆̆ının 3000 gr ve boylarının ise 50 cm civarında olduğu dikkate alındığında çok düşük doğum ağırlıklı bebeklerin araştırmaya dahil edilmemesinden kaynaklanmış olabilir.

Yapılan araştırmalarda antibiyotik tedavisinin, anne sütü dışında beslenmenin ve fototerapi uygulamalarının göbek düşme süresini geciktirdiği bildirilmiştir (3,17-19). Fakat yapılan araştırmada bu değişkenlerin göbek düşme süresini değiştirmediği sadece $\mathrm{Rh}$ Uyuşmazlığı tespit edilen yenidoğanların göbek düşme süreleri diğer yenidoğanlardan anlamlı derecede daha kısa bulunmuştur. Çalışma Rh uyuşmazlığı olan yenidoğanların göbek düşme sürelerinin daha kısa olduğunu tespit eden ilk çalışma olması bakımından literatüre katkı sağlamıştır.

$\mathrm{Bu}$ araştırmanın en önemli kısıtlılıklarından biri örneklem sayısının az olması, verilerin tek merkezden toplanması ve araştırma sonuçlarının sadece araştırmaya katılan anne ve bebeklerini yansitması olup genellenemez olmasidır.

\section{SONUÇ}

$\mathrm{Bu}$ çalışmada yenidoğanların göbek düşme süresi 8.5 gün, umblikal kord klemp mesafesi $2 \mathrm{~cm}$ ve umblikal kord çevresi $1.5 \mathrm{~cm}$ bulunmuştur. Çalışmada göbek düşme süresi ile umblikal kord özellikleri özellikleri arasında ilişki saptanmamıştır. Fakat sezaryen ile doğan yenidoğanlarda göbek düşme süresinin daha uzun, RH uyuşmazlığı sorunu yaşayan yenidoğanlarda ise daha kısa olduğu tespit edilmiştir. Çalışmanın daha fazla yenidoğanın yer aldığı ve tüm umblikal kord özelliklerini ele alan yeni çalışmaların planlanması önerilebilir.

\section{Araştırmanın Etik Yönü}

Araştırmanın yapılabilmesi için hastaneden gerekli izin ve yazarların bulunduğu Üniversitenin Tıp Fakültesi Girişimsel olmayan klinik araştırmalar etik kurulundan (protocol no:2015/635) etik onay ve annelerden de bilgilendirilmiş onam alınmıştır. 


\section{KAYNAKLAR}

1. Genç Koyucu, R., Tosun, Y., \& Çınar, F. (2017). Yenidoğan göbek bakımında klorheksidin, iyot ve alkolün karşılaştırılması. Anadolu Hemşirelik ve Sağllk Bilimleri Dergisi, 20(1), 8-16.

2. Ozdemir, H., Bilgen, H., Topuzoglu, A., Coskun, S., Soyletir, G., Bakir, M., et al. (2017). Impact of different antiseptics on umbilical cord colonization and cord separation time. The Journal of Infection in Developing Countries, 11(02), 152-157.

3. Lyngdoh, D., Kaur, S., Kumar, P., Gautam, V., \& Ghai, S.(2018). Effect of topical application of human breast milk versus $4 \%$ chlorhexidine versus dry cord care on bacterial colonization and clinical outcomes of umbilical cord in preterm newborns. Journal of Clinical Neonatology, 7(1), 25.

4. DSÖ World $\quad$ Health $\quad$ Statistics 2018 https://www.tuseb.gov.tr/enstitu/tacese/yuklemeler/istatistik/9789241565585_eng.pdf (Erişim Tarihi: 9 Şubat 2020).

5. UNICEF 2018 http://www.un.org.tr/unicef-dunya-yenidogan-bebekleri-yuzustu-birakiyor/ (Erişim Tarihi: 9 Şubat 2020).

6. Oladokun, R. E., Orimadegun, A.E., \& Olowu, J. A. (2005). Umbilical Cord Separation Time in Healthy Nigerian Newborns Niger. J Paediatr, 32(1), 19-25.

7. WHO. (2020). World Health Organization (2013). WHO recommendations on "Postnatal care of the mother and newborn".

http://apps. who.int/iris/bitstream/10665/97603/1/9789241506649_eng.pdf (Erişim tarihi: 9 Şubat 2020).

8. Hsu, W. C., Yeh, L. C., Chuang, M. Y., Lo, W. T, Cheng, S. N., \& Huang, C. F. (2010). Umbilical separation time delayed by alcohol application. Annals of Tropical Paediatrics, 30(3), 219-223.

9. Soğukpınar, N., Karaca, S. B., \& Kuru Oktay. A. (2013). Yenidoğanların göbek düşme süresi ve etkileyen etmenler. Anadolu Hemşirelik ve Sağllk Bilimleri Dergisi, 16(1), 17.

10. Abhulimhen-Iyoha, B. I., Ibadin, M. O. (2011). Umbilical cord separation time among infants seen at the immunisation clinic of the university of benin teaching hospital, Nigeria. East African Medical Journal, 88(1), 28-32.

11. Cohen, J. (1988). Statistical Power Analysis For The Behavioral Sciences, 2nd Edition, Hillside, NJ: Erlbaum.

12. Karumbi, J., Mulaku, M., Aluvaala, J., English, M., \& Opiyo, N. (2013). Topical umbilical cord care for prevention of infection and neonatal mortality. The Pediatric Infectious Disease Journal, 32(1), 78.

13. Ahn, S. Y., Chang, Y. S., Kim, S. Y., Sung, D. K., Kim, E. S., Rime, S. Y., et al. (2013). Long-term (postnatal day 70) outcome and safety of intratracheal transplantation of human umbilical cord blood-derived mesenchymal stem cells in neonatal hyperoxic lung injury. Yonsei Medical Journal, 54(2), 416-424.

14. Nourian, M., Allaii, F., \& Heidari, A. (2009). Comparison of the effect of alcohol $70 \%$ versus dry cord care on cord bacterial colonization and cord separation time among newborns. Pak J Med Sci, 25(1), 103-107.

15. Karaçam, Z., Çoban, A., Taşpınar, A. (2018). Temel Ebelik Uygulamaları Rehberler ve Değerlendirme, Ankara Nobel T1p Kitapevi, Ankara, 313.

16. Duchowska, A., \& Azsukowski, P. (2012). Remarks on the length of umbilical arteries in human umbilical cord. A preliminary report. Archives of Perinatal Medicine, 18(3), 169-172. 
17. Abbaszadeh, F., Hajizadeh, Z., \& Jahangiri, M. (2016). Comparing the impact of topical application of human milk and chlorhexidine on cord separation time in newborns. Pakistan Journal Of Medical Sciences, 32(1), 239.

18. Golshan, M., \& Hossein, N. (2013). Impact of ethanol, dry care and human milk on the time for umblical cord seperation. Journal of Pakistan Medical Association, 63(9), 1117-1119.

19. Aghamohammadi, A., Zafari, M., \& Moslemi, L. (2012). Comparing the effect of topical application of human milk and dry cord care on umbilical cord separation time in healthy newborn infants. Iranian Journal of Pediatrics, 22(2), 158. 